\title{
PERAN MEDIA DALAM KOMUNIKASI POLITIK JELANG PEMILIHAN UMUM KEPALA DAERAH TAHUN 2017 DI KABUPATEN ACEH BARAT
}

\author{
Aminah \\ Staf Pengajar Ilmu Komunikasi, FISIP Universitas Teuku Umar \\ Email: Aminahaneukpanga@gmail.com
}

\begin{abstract}
Media in Political Communication ahead of the election widely used by the partner Regent and deputy Regent candidates to influence and seek sympathizers from the community, as happened in Aceh Barat District. Of the three candidates, namely pair H. T. Alaidin Syah and H. Kamaruddin, the couple H. Ramli MS and H. Banta Puteh Syam and the couple Fuad Hadi, SH., MH and drh. Muhammad Arif. This study describes the role of the media are executed by each pair of candidates Regent and deputy Regent of Aceh Barat ahead of the election simultaneously throughout Indonesia. This paper is based on a review of literature as well as by looking at the phenomenon of campaign located along Aceh Barat district. Based on the writer's observation, that each pair has the creativity respectively in the campaign (conveying political messages). Couple H. T. Alaidin Syah and H. Kamaruddin choose a political message by using the phrase "KAMO HANA JANJI ALHAMDULILLAH LE BUKTI YANG NYATA" and "Lanjutkan!". While the pair H. Ramli MS and H. Banta Puteh Syam chose the phrase "KATROEH WATEE Tabalah JASA RAKYAT. Different from other couples Fuad Hadi, SH., MH and drh. Muhammad Arif also choose the appropriate sentence to attract public attention Aceh Barat district by using the phrase "BONGKAR KEBIASAAN LAMA, YANG "TUA" SUDAH PERNAH SAATNYA YANG "MUDA" MEMBENAH. And "SOLUSI NYATA UNTUK ACEH BARAT". Each pair of candidates make the process of media planning and advertising strategies by paying attention to advertising, advertising budgets, strategies and the role of media messages which take into account the selection of the target audience, purpose specification, selection of media and facilities and purchase of media.
\end{abstract}

Keywords: Role of Media, Political Communication and Election

\section{PENDAHULUAN}

Komunikasi politik (political communication) merupakan komunikasi yang melibatkan aktor-aktor politik serta menyampaikan pesan-pesan politik, atau berkaitan dengan kekuasaan, pemerintahan, dan kebijakan pemerintah. Di Indonesia pada saat ini momen-momen politik begitu banyak terjadi yang melibatkan seluruh masyarakat untuk ikut berpartisipasi di dalamnya seperti pada pemilihan umum secara langsung anggota legislatif (Pileg), pemilihan langsung Presiden (Pilpres) dan pemilihan langsung kepala daerah (Pemilukada). Momen-momen politik tersebut meniscayakan lahirnya berbagai bentuk komunikasi politik. Banyak hal yang dapat digunakan sebagai Alat Komunikasi Politik salah satunya yaitu Media.

Pemilukada merupakan ajang pemilihan yang dinantikan oleh masyarakat di setiap daerah tak terkecuali di Kabupaten Aceh Barat. Meskipun penetapan nomor urut calon belum ditetapkan, namun atribut-atribut kampanye mulai bertebaran diseluruh wilayah Aceh Barat yang disebarkan oleh tim pemenangan. Berbagai upaya dilakukan oleh pihak tim pemenangan atau Tim Sukses (TIM SES) untuk memperkenalkan para calon Bupati 
(Cabup) dan calon Wakil Bupati (Cawabup) kepada masyarakat melalui percetakan spanduk, baliho, kaos-kaos, bendera, kartu nama calon, bendera dan lain sebagainya.

Seiring berkembangnya zaman, inovasi dan kreativitas terus dilakukan. Kampanye tidak hanya dilakukan melalui spanduk dan kartu nama. Namun, para TIM SES mulai memperkenalkan Cabup dan Cawabup melalui media massa. Media massa menjadi salah satu sarana yang digunakan oleh partai politik serta para Cabup dan Cawabup untuk mempromosikan visi misi partainya serta visi misi calon kepala daerah kepada masyarakat melalui Internet, Televisi, Radio, serta media massa lainnya yang telah mendominasi kehidupan masyarakat untuk mendapatkan informasi secara cepat.

Media, dalam komunikasi politik memiliki kemampuan untuk mempengaruhi opini dan prilaku pemilih (masyarakat) melalui informasi, reportase, ulasan dan investigasi yang disajikan. Beberapa ahli komunikasi politik memang mengemukakan bagaimana peran media dalam proses politik. Dalam konteks politik modern, media massa tidak hanya menjadi bagian yang integral dari politik, tetapi media massa menjadi sentral dalam politik (Pawito, 2009:91).

Menjelang pemilukada di Kabupaten Aceh Barat, para pasangan Cabup dan Cawabup bersama dengan Partai dan tim penenangannya sendiri mulai marak melakukan kampanye serta menyampaikan visi dan misi setiap calon. Adapun yang menjadi Cabup dan Cawabup di Kabupaten Aceh Barat adalah:

1. Pasangan H. T. Alaidin Syah dan H. Kamaruddin

2. H. Ramli, MS dan H. Banta Puteh Syam

3. Fuad Hadi, SH.,MH dan drh. Muhammad Arif

Dari ketiga pasangan Cabup dan Cawabup Kabupaten Aceh Barat ini menarik untuk dikaji dalam hal peran media kampanye yang dilakukan oleh masing-masing pasangan Cabup dan Cawabup menjelang pemilukada 2017 mendatang. Kajian ini lebih memfokuskan kepada bagaimana peran media dalam komunikasi politik para Cabup dan Cawabup Kabupaten Aceh Barat menjelang pemilukada 2017?

\section{KERANGKA TEORI}

Dalam kajian ini, penulis menggunakan teori-teori yang relevan dari berbagai literatur khususnya tentang komunikasi politik, kampanye dan Media.

\section{Komunikasi Politik}

Komunikasi politik adalah komunikasi yang diarahkan kepada pencapaian suatu pengaruh yang melakukan sedemikian rupa, sehingga masalah yang dibahas oleh jenis kegiatan komunikasi ini, dapat mengikat semua warganya melalui suatu sanksi yang ditentukan bersama oleh lembaga-lembaga politik (Astrid, S. Soesanto, 1980:2). Mengenai komunikasi politik ini (political communication) Kantaprawira (1983:25) memfokuskan pada kegunaanya, yaitu untuk menghubungkan pikiran politik yang hidup dalam masyarakat, baik pikiran antar golongan, institusi, asosiasi, ataupun sektor kehidupan politik masyarakat dengan sektor kehidupan politik pemerintah.

Pendapat lain tentang komunikasi politik juga disampaikan oleh Lasswell (dalam Varma, 1995:258) memandang orientasi komunikasi politik telah menjadikan dua hal sangat jelas: pertama, bahwa komunikasi politik selalu berorientasi pada nilai atau berusaha mencapai tujuan; dan kedua, bahwa komunikai politik bertujuan menjangkau masa depan dan bersifat mengantisipasi serta berhubungan dengan masa lampau dan senantiasa memperhatikan kejadian masa lalu. 
Selanjutnya Komunikator politik Menurut Nimmo, salah satu ciri komunikasi ialah bahwa orang jarang dapat menghindari dan keturutsertaan. Hanya dihadiri dan diperhitungkan oleh seorang lain pun memiliki nilai pesan. Dalam arti yang paling umum kita semua adalah komunikator, begitu pula siapa pun yang dalam setting politik adalah komunikator politik (2000:28). Berdasarkan hal tersebut, jelas bahwa para komunikator harus diidentifikasi serta kedudukan mereka di dalam masyarakat harus ditetapkan. Untuk keperluan ini Nimmo (2000:30) mengidentifikasi tiga kategori politikus, yaitu yang bertindak sebagai komunikator pilitik, komunikator profesional dalam politik, dan aktivis atau komunikator paruh waktu (part time).

\section{Kampanye}

Pfau dan Parot (Venus, 2004:8) memberikan pengertian terkait Kampanye sebagai berikut: "campaign is conscious, sustained and incremental process designed to be implemented over a specified periode of time for the purpose of influencing a specified Audience" (kampanye adalah suatu proses yang dirancang secara sadar, bertahap dan berkelanjutan yang dilaksanakan pada rentang waktu dengan tujuan mempengaruhi masyarakat sebagai sasaran yang telah ditetapkan). Sementara menurut Kotler dan Roberto (1989) dalam Cangara (2009:284) kampanye adalah sebagai berikut: "a campaign is an organized effort conducted by one group (the change agent) which intends to persuade others (the target adopters), to accept, modify, or abandon certain ideas, attitudes, practices and behavior". (Kampanye ialah sebuah upaya yang dikelola oleh satu kelompok, (agen perubahan) yang ditujukan untuk mempersuasi target sasaran agar bisa menerima, memodifikasi atau membuang ide, sikap dan perilaku tertentu). Berdasarkan defenisi tersebut maka setiap aktifitas kampanye setidaknya harus mengandung empat hal yakni: (1) Tindakan kampanye yang ditujukan untuk menciptakan efek atau dampak tertentu, (2) Jumlah masyarakat sebagai sasaran yang besar, (3) Biasanya dipusatkan dalam kurun waktu tertentu, dan (4) Melalui serangkaian tindakan komunikasi yang terorganisasi. Selain keempat hal tersebut, kampanye juga memiliki karakteristik lain, yaitu sumber yang jelas, yang menjadi penggagas, perancang, penyampai sekaligus penanggung jawab suatu produk kampanye, sehingga setiap individu yang menerima pesan kampanye dapat mengidentifikasi dan mengevaluasi kredibilitas sumber pesan setiap saat.

\section{Media}

Media adalah alat atau sarana yang digunakan untuk menyampaikan pesan dari komunikator kepada masyarakat. Cangara (2004:119) mengemukakan bahwa media komunikasi dapat dibedakan atas empat macam, yaitu media antarpribadi, media kelompok, media publik, dan media massa.

1. Media antarpribadi yaitu untuk hubungan perorangan (antarpribadi), maka media yang tepat digunakan ialah kurir (utusan), surat dan telepon.

2. Media Kelompok yaitu aktivitas komunikasi yang melibatkan masyarakat lebih dari 15 orang, maka media komunikasi yang banyak digunakan adalah media kelompok, misalnya, rapat, seminar dan komperensi.

3. Media Publik yaitu media yang digunakan jika masyarakat yang ikut serta adalah lebih dari 200-an, misalnya rapat akbar, rapat raksasa dan lainnya yang serupa. 


\section{Proses Perencanaan Media}

Perencanaan media untuk kampanye merupakan tindakan peran dan sangat penting sehingga perencana yang akan "menjual" calonnya mengetahui media yang cocok dan strategi kreatif apa yang akan digunakan serta perencanaan anggaran yang matang. Menurut Shimp (2003: 5) perencanaan media meliputi proses penyusunan rencana penjadwalan yang menunjukkan bagaimana waktu dan ruang periklanan akan mencapai tujuan pemasaran. Perencanaan media meliputi koordinasi tiga tingkat perumusan strategi yaitu: strategi pemasaran, strategi periklanan, dan strategi media. Proses perencanaan media dapat dilihat pada gambar berikut ini:

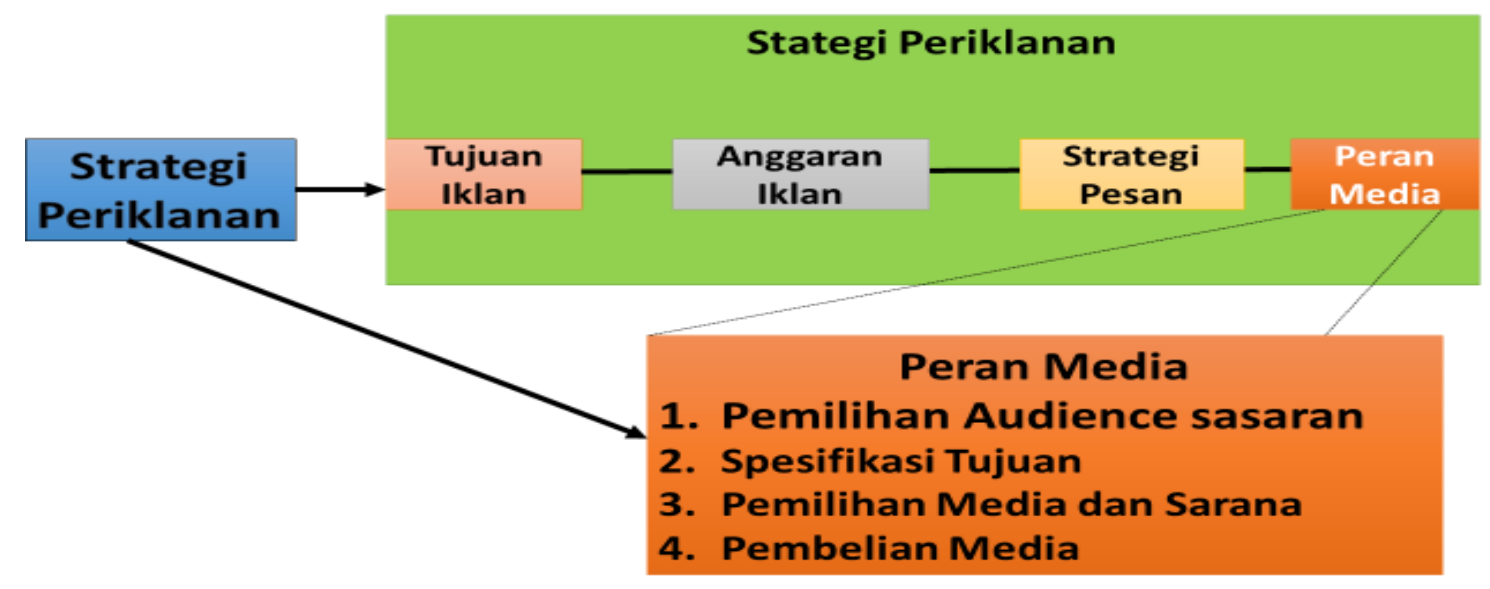

GAMBAR 1. PROSES PERENCANAAN MEDIA

Sumber: Shimp, Terence A. 2003. Periklanan dan Promosi.

Berdasarkan gambar diatas dapat dilihat bahwa strategi media terdiri dari empat kegiatan yang saling berkaitan yaitu:

1. Memilih Audience sasaran;

2. Menspesifikasi tujuan media;

3. Memilih kategori media dan sasaran; serta

4. Membeli media.

\section{METODE}

Metode yang digunakan dalam penelitan ini yaitu metode kualitatif deskriptif. Teknik pengumpulan data dilakukan dengan dua cara yaitu studi kepustakaan dan ke lapangan. Studi kepustakan dilakukan dengan mencari berbagai referensi yang mendukung terhadap kasus yang diangkat. Sedangkan ke lapangan dengan observasi serta melihat fenomena kampanye yang sedang marak terjadi di Kabupaten Aceh Barat menjelang pemilukada 2017.

\section{PEMBAHASAN DAN ANALISIS}

Analisis dalam kajian ini berhubungan dengan pemanfaatan media oleh para aktor politik sebagai fokus kajian adalah peran media dalam komunikasi politik jelang Pilkada Tahun 2017 di Kabupaten Aceh Barat yakni pasangan H. T Alaidinsyah dan H. Kamaruddin (ALAIKA), pasangan Ramli, MS dan H. Banta Puteh Syam serta pasangan Fuad Hadi, SH.,MH dan Muhammad (Fuad-Arif) 


\section{Peran Media Dalam Komunikasi Politik}

Peran media harus diketahui oleh setiap partai politik maupun pasangan Cabup dan Cawabup karena peran media berhubungan erat dengan efektivitas pesan politik yang ingin disampaikan. Selain itu, media yang digunakan untuk melakukan kampanye para pasangan Cabup dan Cawabup tentunya disesuaikan dengan kondisi masyarakat di daerahnya. Disamping perencanaan media yang tepat, penentuan segmentasi juga penting dilakukan untuk menentukan media yang cocok digunakan dan bagaimana strategi kreatifnya dalam menyampaikan pesan politik (komunikasi dan visual). Rothschild (1978) menjelaskan pilihan media merupakan salah satu faktor yang sangat penting dalam penyampaian pesan politik ke publik. Mengetahui adanya perbedaan tingkat penyampaian media (TV, radio, media cetak dan lainnya) dalam suatu wilayah penting dilakukan untuk menjamin efektivitas pesan politik yang disampaikan (Firmanzah, 2008: 204).

Menjelang pelaksanaan pemilukada serentak di Indonesia, khususnya di Aceh Barat, para pasangan Cabup dan Cawabup Kabupaten Aceh Barat mulai mengkampanyekan diri sebagai orang yang layak memimpin masyarakat Kabupaten Aceh Barat selama lima tahun kedepan yang terhitung sejak tahun 2017-2022. Berbagai iklan politik para pasangan Cabup dan Cawabup mulai banyak menghiasi media baik di media cetak maupun elektronik hingga diruang-ruang publik.

Pemilukada di Kabupaten Aceh Barat diikuti oleh tiga pasangan terbaik yang telah mencalonkan diri sebagai pasangan Cabup dan Cawabup periode 2017-2022. Masingmasing pasangan Cabup dan Cawabup Kabupaten Aceh Barat itu adalah pasangan H. T Alaidinsyah dan H. Kamaruddin (ALAIKA), pasangan Ramli, MS dan H. Banta Puteh Syam serta pasangan Fuad Hadi, SH.,MH dan Drh. Muhammad Arif (Fuad-Arif).

Dalam menganalisis peran media dalam komunikasi politik, ketiga pasangan di atas tidak terlepas dari peran periklanan yang dilakukan masing-masing pasangan, dimana ada empat tahapan strategi periklanan yaitu tujuan iklan, anggaran iklan, strategi pesan dan strategi media. Adapun strategi media terdiri dari empat kegiatan yang saling berkaitan, yaitu: (a) Memilih Audience sasaran, (b) Menspesifikasi tujuan media, (c) Memilih kategori media dan sasaran serta (d) Membeli media (Shimp, Terence A. 2003).

Analisis mendalam lebih penulis fokuskan pada tahapan peran pesan yang dititik beratkan pada peran komunikasi dan visual yang digunakan dan tahapan peran media itu sendiri. Strategi pembelian media merupakan hal khusus dalam peran media dimana yang dimaksud adalah kepemilik pemasar tehadap media. Namun dalam kajian ini pembelian media lebih dimaksudkan pada pembelian waktu (dimedia elektronik) atau tempat (dimedia cetak).

\section{Peran Media dalam Kampanye Pasangan H. $T$ Alaidinsyah dan $H$. Kamaruddin (ALAIKA)}

Pasangan H. T Alaidinsyah dan H. Kamaruddin (ALAIKA) merupakan satu-satunya pasangan yang paling banyak dukungan dari partai politik. H. T Alaidinsyah atau sering disebut dengan sebutan Haji Tito merupakan pasangan incumbent yang kembali bertarung pada pemilukada di Kabupaten Aceh Barat serta berpasangan dengan H. Kamaruddin yang merupakan Ketua umum DPD II Partai Golkar Aceh Barat sekaligus masih menjabat sebagai Wakil Ketua Dewan Perwakilan Rakyat Kabupaten Aceh Barat sebagai wakilnya di Pilkada 2017. Pasangan ini dideklarasikan pada hari selasa tanggal 23 Agustus 2016 di posko utama pemenangannya, jalan Nasional, Drien Rampak, Kecamatan Johan Pahlawan. Salah satu media (acehtrend.co) menyebutkan bahwa alasan H. T Alaidinsyah menjadikan H. Kamaruddin sebagai Cawabup pada pimilukada di Aceh Barat pada tahun 2017-2022 yaitu H. Kamaruddin adalah sosok yang memiliki keteguhan dan konsisten dalam bekerja 
serta mempunyai integeritas yang tinggi. Selain itu, keputusan ini, sudah menjadi kesepakatan bersama partai-partai pengusung, termasuk aspirasi dari elemen masyarakat. Adapun partai partai yang mendukung pasangan Cabup dan Cawabup dari H. T Alaidinsyah dan H. Kamaruddin yaitu (1) Partai Golongan Karya (Golkar), (2) Partai Demokrasi Indonesia Perjuangan (PDIP), (3) Partai Persatuan Pembangunan (PPP), (4) Partai Nasional Demokrat (Nasdem), (5) Partai Demokrat, (6) Partai Keadilan Sejahtera (PKS), (7) Partai Kebangkitan Bangsa (PKB) dan (8) Partai Amanat Nasional (PAN).

Pasca deklarasi pasangan calon $\mathrm{H}$. T Alaidinsyah dan H. Kamaruddin yang diusung melalui delapan partai Nasional ini digelar, para tim pemenangan (TIM SES) mulai melakukan berbagai kampanye atau membuat strategi untuk memenangkan hati masyarakat Kabupaten Aceh Barat pada pemilukada 2017 nanti. Iklan politiknya terdapat di berbagai media baik dimedia cetak maupun media elektronik. Iklan politik H. T Alaidinsyah dan H. Kamaruddin terpasang media cetak seperti di surat kabar dan majalah, media elektronik seperti di Radio serta di media-media lainnya seperti internet, banner, baliho, billboard, stiker, gimmick, kaos, sampai pada vehicle advertising dan bendera serta atribut-atribut lain yang mendukung.

\section{Proses Perencanaan Media dalam Komunikasi Politik H. T Alaidinsyah dan H. Kamaruddin}

Berdasarkan analisis penulis terhadap strategi media dalam komunikasi politik $\mathrm{H}$. T Alaidinsyah dan H. Kamaruddin melalui empat tahap proses perencanaan media (strategi periklanan) berikut ini:

\section{a. Tujuan Iklan}

Tujuan iklan politik H. T Alaidinsyah dan H. Kamaruddin lebih kepada pembangunan citra H. T Alaidinsyah dan H. Kamaruddin dimata publik masyarakat Kabupaten Aceh Barat pada umumnya. Sedangkan populeritas H. T Alaidinsyah dan H. Kamaruddin tidak diragukan lagi karena kepopuleran $\mathrm{H}$. T Alaidinsyah sebagai pengusaha dan salah satu orang kaya di Kabupaten Aceh Barat serta sebagai calon bupati yang incumbent. Citra yang dibangun oleh $\mathrm{H}$. $\mathrm{T}$ Alaidinsyah dan $\mathrm{H}$. Kamaruddin bahwa selama ini, dibawah kepemimpinan H. T Alaidinsyah, Kabupaten Aceh Barat telah berhasil memajukan dunia pendidikan Di Aceh Barat dan pembangunan infrastruktur yang merata.

Selain dari H. T Alaidinsyah hal yang juga dibangun dari sisi H. Kamaruddin. Selama ini H. Kamaruddin dianggap orang yang memiliki integeritas yang tinggi serta sosok yang pekerja keras. Selama menjabat sebagai Wakil Dewan Perwakilan Rakyat di Kabupaten Aceh Barat H. Kamaruddin dianggap cukup berkompeten serta mampu membawa perubahan Kabupaten Aceh Barat kearah yang lebih baik.

\section{b. Anggaran Iklan}

Untuk mendukung kesuksesan iklan politik tentu dibutuhkan anggaran yang cukup besar baik dari dana pribadi maupun sponsor. Dari iklan politik pasangan H. T Alaidinsyah dan H. Kamaruddin diberbagai media dan diberbagai tempat menunjukkan bahwa anggaran iklan yang dikeluarkan sangatlah besar dibanding dengan pasangan lain. Disamping penggunaan berbagai macam media kampanye, bersarnya anggaran iklan pasangan $\mathrm{H}$. T Alaidinsyah dan H. Kamaruddin juga dipengaruhi oleh jangka waktu iklan dan frekuensi pemasangannya dimulai. Perkiraan kasar penulis, anggaran iklan yang digolontorkan pasangan H. T Alaidinsyah dan H. Kamaruddin mencapai puluhan juta rupiah.

\section{c. Strategi Pesan}


Strategi pesan dalam iklan pasangan H. T Alaidinsyah dan H. Kamaruddin, penulis membaginya menjadi dua strategi, yakni strategi komunikasi dan strategi visual.

\section{Strategi Komunikasi}

Strategi komunikasi pasangan $\mathrm{H}$. T Alaidinsyah dan H. Kamaruddin dalam iklan politiknya sangat berbeda dari dua pesaingnya. Beberapa hal yang ditinjolkan dalam iklan adalah inisial nama H. T Alaidinsyah dengan sebutan "HAJI TITO", dan H. Kamaruddin disebut sebagai "HAKAM". Dalam beberapa spanduk dan baliho selain sebagai sebutan HAJI TITO dan HAKAM, pasangan ini juga disingkatkan namanya menjadi "ALAIKA" dan diikuti oleh kalimat "KAMO HANA JANJI ALHAMDULILLAH LE BUKTI YANG NYATA" yang memiliki arti "Kami tidak berjanji Alhamdulillah sudah banyak bukti nyata" dan juga diikuti kata "Lanjutkan" pada beberapa spanduk yang berbeda. Kalimat "KAMO HANA JANJI ALHAMDULILLAH LE BUKTI YANG NYATA" lebih memberikan pernyataan bahwa pasangan H. T Alaidinsyah dan H. Kamaruddin tidak mengubarkan janji-janji kepada masyarakat akan tetapi selama menjabat sebagai Bupati sebelumnya, H. T Alaidinsyah telah membuktikan bahwa banyak perubahan dan inovasi yang dilakukannya, sedangkan kata "Lanjutkan" lebih kepada kata yang digunakan untuk menyampaikan bahwa pasangan $\mathrm{H}$. T Alaidinsyah dan H. Kamaruddin perlu diberikan kesempatan lima tahun kedepan untuk menjalankan program-pogram yang telah dibentuk secara tuntas.

Penggunaan pesan politik pasangan $\mathrm{H}$. T Alaidinsyah dan H. Kamaruddin dimedia cetak dan elektronik juga tetap konsisten. Selain kata "Lanjutkan" dan "KAMO HANA JANJI ALHAMDULILLAH LE BUKTI YANG NYATA" ucapan "PILIHAN BOLEH BEDA GEUTANYOE TETAP MESYEDARA APAPUN YANG TERJADI" juga terdapat dalam media kampanye pasangan $\mathrm{H}$. T Alaidinsyah dan $\mathrm{H}$. Kamaruddin khususnya media luar ruang (baliho, billboard, spanduk, maupun banner). Pesan politik yang berbeda terdapat pada media kampanye lain, yakni iklan di mobil yang bertuliskan "LASKAR GARUDA BERSAMAMU, H. TITO-H. KAMARUDDIN PILIHANKU".

\section{$>\quad$ Strategi Visual}

Selain strategi komunikasi, strategi visual dalam iklan politik pasangan H. T Alaidinsyah dan H. Kamaruddin pun sangat berbeda dengan pasangan lain, yakni keberanian dari tim kreatif $\mathrm{H}$. T Alaidinsyah dan $\mathrm{H}$. Kamaruddin menggunakan gambar wajah $\mathrm{H}$. $\mathrm{T}$ Alaidinsyah dan H. Kamaruddin dengan latar belakang ilustrasi kibaran bendera Merah Putih dan tipografi (huruf) inisial "ALAIKA" yang berwana Biru, hijau dan kuning lebih menarik jika dibanding dengan tipografi lain. 


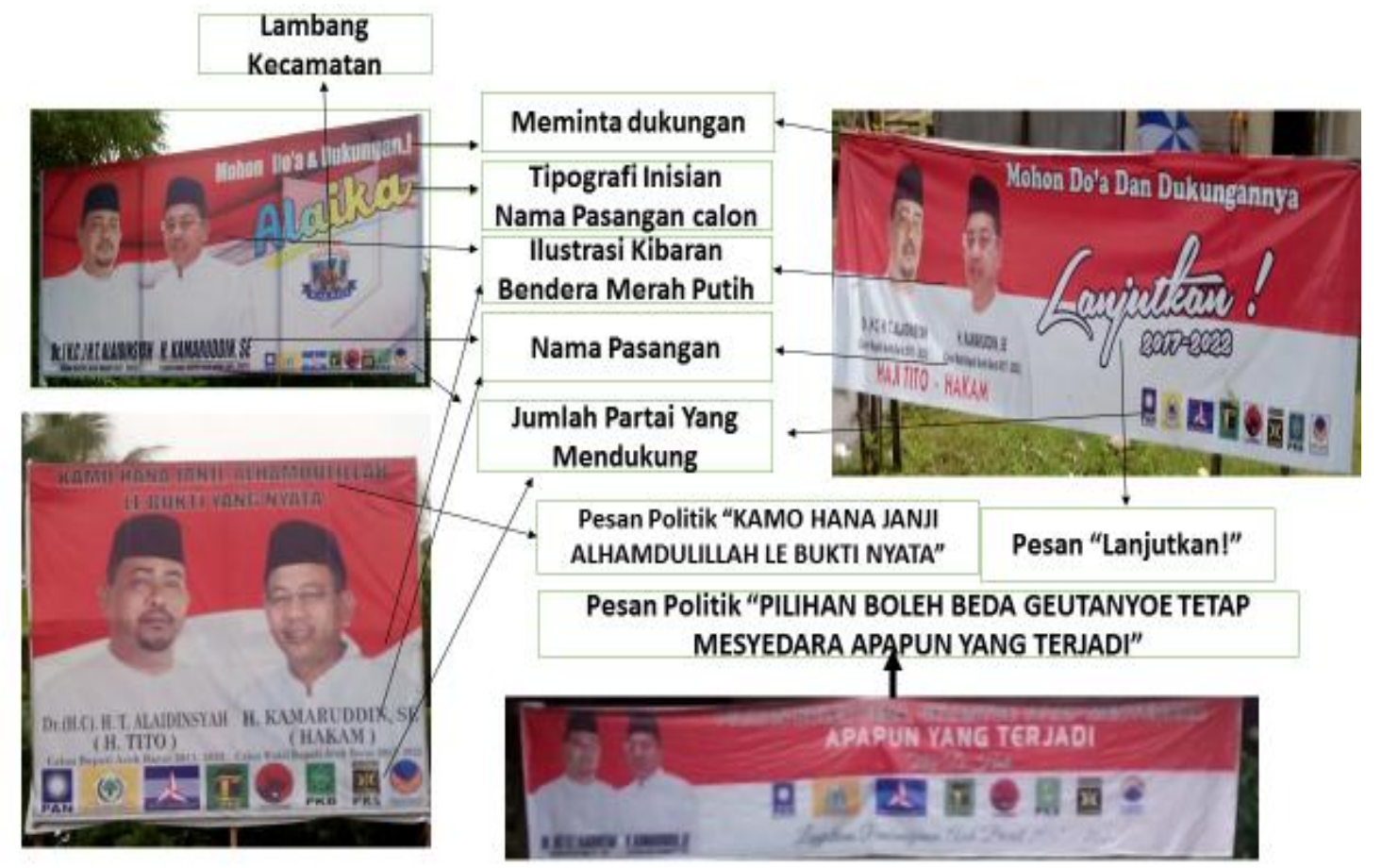

Gambar 2. Strategi Visual Iklan Politik Pasangan H. T Alaidinsyah dan H.

Sumber: Foto Dokumen Pribadi

\section{Kamaruddin (ALAIKA)}

\section{Strategi Media Pasangan H. T Alaidinsyah dan H. Kamaruddin (ALAIKA)}

\section{Memilih Audience Sasaran}

Menentukan Audience sasaran merupakan syarat pertama yang harus dilakukan agar strategi media berhasil. Ada empat faktor utama untuk menentukan (mensegmentasi) Audience sasaran dalam strategi media, yakni geografis, demografis, pemakaian produk, dan psikografis/gaya hidup. Menganalisis iklan-iklan politik pasangan H. T Alaidinsyah dan H. Kamaruddin, segmentasi Audience sasaran tidak hanya terbatas pada kalangan internal partai namun lebih kepada masyarakat secara luas. Dari strategi yang digunakan konsultan politik pasangan $\mathrm{H}$. T Alaidinsyah dan $\mathrm{H}$. Kamaruddin bahwa empat faktor segmentasi yang dibangun.

\section{Menentukan Tujuan Media}

Dalam menentukan tujuan media terdapat lima tujuan yang merupakan dasar dari perencanaan media, yaitu jangkauan, frekuensi, bobot, kontinuitas, dan biaya. Jangkauan adalah kepada jumlah Audience sasaran yang harus melihat, membaca, atau mendengar pesan periklanan dalam masa tertentu. Frekuensi adalah berapa sering audiens sasaran dihadapkan pada periklanan selama ini. Bobot adalah berapa banyak total iklan yang dibutuhkan selama masa tertentu untuk mencapai tujuan jangkauan dan frekuensi. Kontinuitas adalah bagaimana anggaran periklanan harus dialokasikan sepanjang waktu. Sedangkan biaya adalah apa cara yang paling murah untuk mencapai tujuan yang lain. 
Mengamati penggunaan media untuk iklan politik pasangan $\mathrm{H}$. T Alaidinsyah dan $\mathrm{H}$. Kamaruddin terlihat bahwa pasangan ini ingin menjangkau seluruh audiens sasaran yaitu masyarakat Kabupaten Aceh Barat. Frekuensi iklanpun begitu gencar selama beberapa bulan penuh sebelum pelaksanaan pemilukada. Total iklan politik pasangan $H$. T Alaidinsyah dan H. Kamaruddin lebih banyak dibandingkan dengan iklan Pasangan pasangan Ramli, MS dan H. Banta Puteh Syam dan pasangan Fuad Hadi, SH.,MH dan drh. Muhammad Arif (Fuad-Arif). Karena didukung oleh dana dan partai yang cukup besar, kontinuitas iklan politik pasangan $\mathrm{H}$. T Alaidinsyah dan H. Kamaruddin terus dilakukan sepanjang waktu sampai pelaksanaan Pemilukada.

\section{Pemilihan Media dan Sarana}

Pemilihan media dan sarana guna mendukung kampanye politik pasangan $\mathrm{H}$. T Alaidinsyah dan H. Kamaruddin, berbagai media digunakan secara maksimal oleh timsuksesnya seperti media massa cetak, media massa elektronik (radio lokal) serta media cetakan seperti billboard, baliho, banner, spanduk, stiker, kaos, bendera, umbul-umbul, maupun iklan dikendaraan (vehicle advertising).

\section{$>\quad$ Pembelian Media (Waktu Tayang dan Tempat Iklan)}

Pembelian media lebih kepada pembelian waktu tayang (spot) iklan dimedia elektronik dan membeli halaman dimedia cetak. Di media cetak iklan politik pasangan $\mathrm{H}$. T Alaidinsyah dan H. Kamaruddin sering menjadi sorotan para media.

\section{Peran Media dalam Kampanye pasangan Ramli, MS dan H. Banta Puteh Syam}

Berbeda dengan pasangan H. T Alaidinsyah dan H. Kamaruddin, pasangan Ramli, MS dan H. Banta Puteh Syam adalah pasangan yang juga telah mendeklarasikan diri untuk menjadi Cabup dan Cawabup Kabupaten Aceh Barat periode 2017-2022. Pendaftaran ke Kantor Komisi Independen Pemilihan (KIP) sudah dilaksanakan pada hari rabu tanggal 21 September 2016. Deklarasi pasangan Ramli, MS dan H. Banta Puteh Syam dihadiri oleh semua lapisan masyarakat dan anggota Partai Aceh. Sejak mendeklarasikan diri, banyak iklan politik pasangan Ramli, MS dan H. Banta Puteh Syam dimedia seperti halnya pasangan $\mathrm{H}$. T Alaidinsyah dan $\mathrm{H}$. Kamaruddin yang meluncurkan iklan politiknya diberbagai media.

\section{Proses Perencanaan Media dalam Kampanye pasangan Ramli, MS dan Banta Puteh}

Analisis penulis terhadap peran media dalam komunikasi politik pasangan H. Ramli, MS dan H. Banta Puteh Syam melalui empat tahap proses perencanaan media (peran periklanan) sebagai berikut ini:

\section{a. Tujuan Iklan}

Tujuan iklan politik pasangan H. Ramli, MS dan H. Banta Puteh Syam sama seperti pasangan H. T Alaidinsyah dan H. Kamaruddin, yakni untuk membangun citra dimata masyarakat Kabupaten Aceh Barat. Popularitas Ramli, MS yang merupakan memang mantan Bupati Aceh Barat periode 2007-2012. Pasangan Ramli, MS dan H. Banta Puteh Syam tidak kurang populer dikalangan masyarakat. Selain itu, saat ini pasangan H. Ramli, MS yang sedang menjabat sebagai wakil ketua DPRK Aceh Barat, H. Ramli, MS memiliki power yang membuatnya memiliki kesempatan untuk lebih dekat dengan rakyat. 
Sepertinya pasangan H. Ramli, MS dan H. Banta Puteh Syam siap bertarung meskipun dikepung oleh delapan partai politik nasional.

\section{b. Anggaran Iklan}

Penggunaan anggaran untuk biaya iklan politik pasangan H. Ramli, MS dan H. Banta Puteh Syam juga hampir sama dengan pasangan H. T Alaidinsyah dan H. Kamaruddin. Anggaran iklan politik tentu saja berasal dari dana pribadi, partai atau sponsor lainnya. Pengunaan media kampanye yang tidak terbatas dan frekuensi yang tidak terbatas pula mendorong penggunaan anggaran untuk iklan politik H. Ramli, MS dan H. Banta Puteh Syam pun terbilang cukup besar. Dari perkiraan kasar penulis, anggaran iklan politik H. Ramli, MS dan H. Banta Puteh Syam tidak kurang dari puluhan juta rupiah.

\section{c. Strategi Pesan}

Strategi pesan dalam iklan pasangan H. Ramli, MS dan H. Banta Puteh Syam, penulis membaginya menjadi dua strategi, yakni strategi komunikasi dan strategi visual.

\section{Strategi Komunikasi}

Strategi komunikasi pasangan H. Ramli, MS dan H. Banta Puteh Syam dalam iklan politiknya menggunakan kalimat yang "KATROEH WATEE TABALAH JASA RAKYAT". Kalimat sederhana tetapi mengandung visi yang jauh kedepan, dimana kebaikan bagi rakyat adalah ketepatan dan memperjuangkan serta membalas jasa-jasa rakyat. Dalam iklan politik dimedia cetakan, pasangan H. Ramli, MS dan H. Banta Puteh Syam juga sering menonjol namanya di media. Kalimat yang berbeda akan tetapi mengandung isi yang sama terdapat pada Spanduk dukungan untuk pasangan $\mathrm{H}$. Ramli, MS dan H. Banta Puteh Syam yang dipasang di beberapa persimpangan Jalan yang berbunyi "SAATNYA KITA BALAS JASA RAKYAT".

\section{Strategi Visual}

Strategi visual dalam iklan politik pasangan H. Ramli, MS dan H. Banta Puteh Syam berbeda dengan pasangan lain, tulisan nama pasangan Cabup dan Cawabub ini ditulis secara jelas dan tidak ada inisial yang digunakan. Selain itu, dalam spanduk dan baliho dari pasangan H. Ramli, MS dan H. Banta Puteh Syam menggunakan lambang partai Aceh serta menggunakan latar belakang yang merah sebagai lambang Partai Aceh. Pada strategi visual ini pasangan H. Ramli, MS dan H. Banta Puteh Syam masih menggunakan image foto dirinya dengan dengan menggunakan pakaian adat Aceh. Perbedaan mendasar pada visual yang digunakan pasangan H. Ramli, MS dan H. Banta Puteh Syam dan pasangan H. T Alaidinsyah dan $\mathrm{H}$. Kamaruddin adalah jenis pakaian yang digunakan pada gambar diri masing-masing (pasangan H. Ramli, MS dan H. Banta Puteh Syam menggunakan image foto dengan menggunakan pakaian adat sedangkan pasangan $\mathrm{H}$. T Alaidinsyah dan $\mathrm{H}$. Kamaruddin menggunakan image foto yang berpakaian Putih dan menggunakan peci berwarna hitam). 


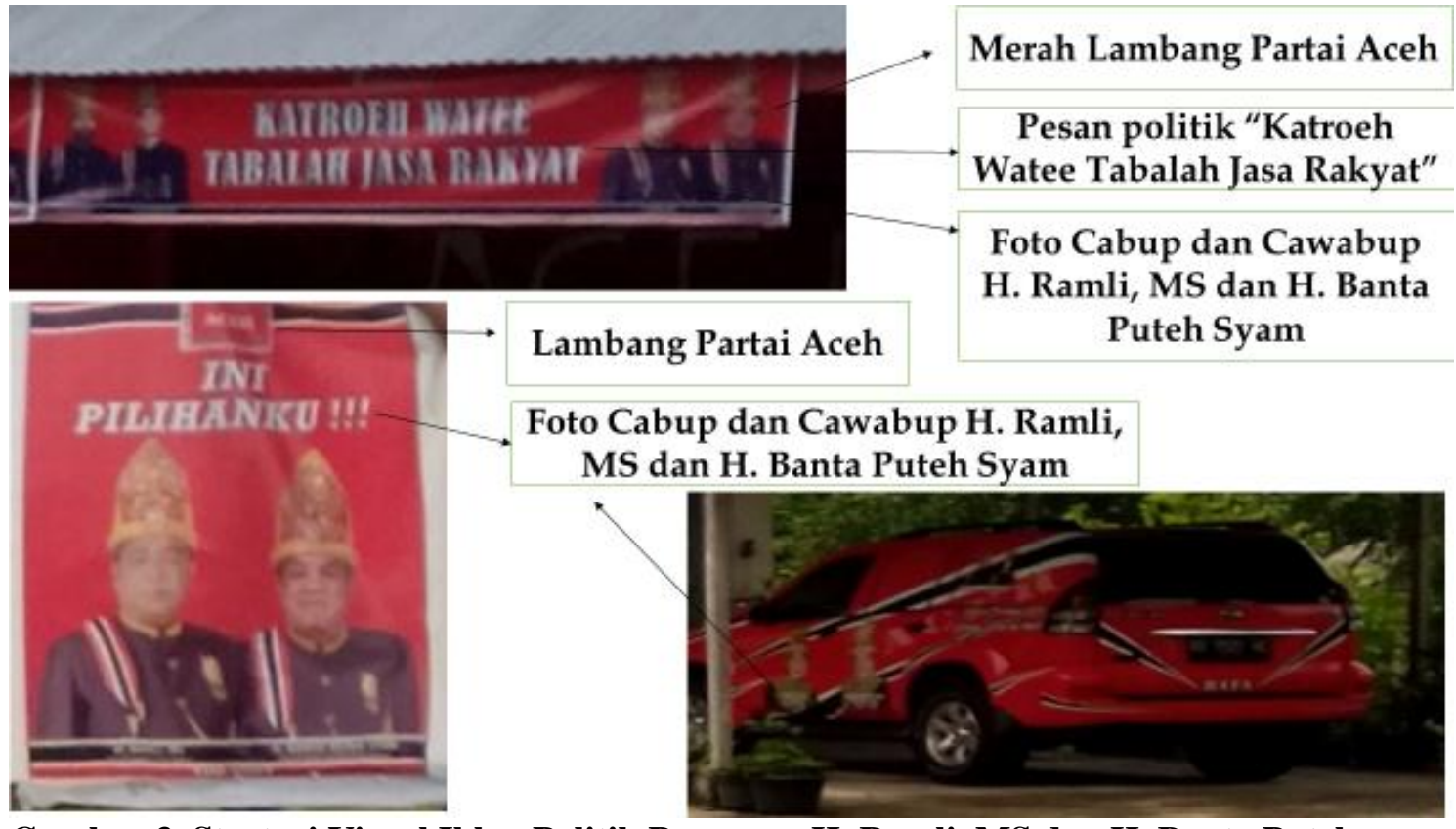

Gambar 3. Strategi Visual Iklan Politik Pasangan H. Ramli, MS dan H. Banta Puteh Syam

Sumber: Foto Dokumen Pribadi

\section{Strategi Media pasangan Ramli, MS dan Banta Puteh}

Strategi media yang digunakan oleh pasangan H. Ramli, MS dan H. Banta Puteh Syam adalah sebagai berikut:

\section{Memilih Audience Sasaran}

Audience sasaran yang dituju dalam iklan politik pasangan H. Ramli, MS dan H. Banta Puteh Syam adalah seluruh masyarakat Kabupaten Aceh Barat. Hal ini terlihat dari pesan politik yang digunakan "Saatnya kita Balas Jasa Rakyat".

\section{Menentukan Tujuan Media}

Dalam menentukan tujuan media, pasangan H. Ramli, MS dan H. Banta Puteh Syam juga tidak sedikit serta kontinuitasnya tetap terjaga. Dari penggunaan media kampanye yang tidak terbatas inilah membuat biaya iklan pasangan $\mathrm{H}$. Ramli, MS dan $\mathrm{H}$. Banta Puteh Syam hampir sebanding dengan pasangan $\mathrm{H}$. T Alaidinsyah dan $\mathrm{H}$. Kamaruddin.

\section{$>\quad$ Pemilihan Media dan Sarana}

Sebagaimana dijelaskan sebelumnya bahwa media kampanye pasangan H. Ramli, MS dan H. Banta Puteh Syam sangat terwakili penggunaan medianya baik cetak maupun elektronik. Media cetak yang digunakan adalah surat kabar, media elektronik adalah radio serta media cetakan seperti billboard, baliho, spanduk dan poster.

\section{$>\quad$ Pembelian Media (Waktu Tayang dan Tempat Iklan)}

Pembelian media dalam hal ini adalah pembelian waktu tayang (spot) iklan dimedia elektronik dan membeli halaman dimedia cetak. Di media cetak iklan politik 
pasangan H. Ramli, MS dan H. Banta Puteh Syam juga sering disorot oleh kamera dan berita lokal seperti Serambi Indonesia, sedangkan di media online yaitu pada media AcehTrend.co dan AntarNews.

\section{Peran Media dalam Kampanye pasangan Fuad Hadi, SH.,MH dan Drh. Muhammad Arif (Fuad-Arif)}

Pasangan Fuad Hadi, SH.,MH dan drh. Muhammad Arif (Fuad-Arif) merupakan pasangan Cabup dan Cawabup Kabupaten Aceh Barat yang maju melalui jalur independen. Pasangan Cabup dan Cawabup muda ini memiliki energi yang berlebih untuk ambil bagian dalam kompetisi Pemilukada 2017 di Kabupaten Aceh Barat. Saat mengantarkan syarat dukungan Kartu Tanda Penduduk (KTP) ke Kantor KIP pasangan muda yang juga dimotori oleh orang-orang muda menyerahkan 7 ribu lebih KTP dari 11 kecamatan. Ini merupakan jumlah yang melebihi dari syarat yang hanya 5 ribu lebih KTP di enam kecamatan.

\section{Strategi Media dalam Komunikasi Politik Pasangan Fuad Hadi, SH.,MH dan drh. Muhammad Arif}

Dari kedua Cabup dan Cawabup di atas, pasangan Fuad Hadi, SH.,MH dan drh. Muhammad Arif merupakan pasangan yang menyerahkan syarat foto copy KTP masyarakat sebanyak 7 ribu pada hari selasa tanggal 09 Agustus 2016. Kemunculan pasangan muda Fuad Hadi, SH.,MH dan drh. Muhammad Arif secara tiba-tiba, walaupun sebelumnya ada wacana untuk mencalonkan diri membuat kedua kubu yang ada sebelumnya lebih meningkatkan strategi dalam meraih dukungan. Walaupun demikian, pasangan Fuad Hadi, SH.,MH dan drh. Muhammad Arif juga tetap memanfaatkan media untuk menayangkan iklan politiknya.

\section{Proses Perencanaan Media Pasangan Fuad Hadi, SH.,MH dan drh. Muhammad Arif.}

Berdasarkan analisis penulis terhadap peran media dalam komunikasi politik pasangan Fuad Hadi, SH.,MH dan drh. Muhammad Arif melalui empat tahap proses perencanaan media (strategi periklanan) berikut ini:

\section{a. Tujuan Iklan}

Tujuan iklan politik pasangan Fuad Hadi, SH.,MH dan drh. Muhammad Arif lebih kepada memberikan kesadaran kepada masyarakat Kabupaten Aceh Barat bahwa mereka sebagai tokoh muda maju sebagai pasangan Cabup dan Cawabup periode 2017-2022. Pendukung dalam iklan politiknya adalah para pemuda yang merupakan basis massa pendukungnya.

\section{b. Anggaran Iklan}

Anggaran untuk iklan politik pasangan Fuad Hadi, SH.,MH dan drh. Muhammad Arif terhitung lebih kecil dibanding dengan dua pasangan lain yang lebih banyak memasang iklan politik mereka disepanjang jalan serta diberbagai media lainnya.

\section{c. Strategi Pesan}

Strategi pesan dalam iklan pasangan Fuad Hadi, SH.,MH dan drh. Muhammad Arif, penulis membaginya menjadi dua strategi, yakni strategi komunikasi dan strategi visual.

\section{Strategi Komunikasi}

Strategi komunikasi yang digunakan dalam iklan politik pasangan Fuad Hadi, SH.,MH dan drh. Muhammad Arif mengandung makna yang mendalam yaitu "BONGKAR 
KEBIASAAN LAMA, YANG "TUA" SUDAH PERNAH SAATNYA YANG "MUDA" MEMBENAH". Dari kalimat yang pendek ini, sungguh mengunggah hati para pemudapemudi untuk menyatukan visi dan misi mereka dalam membangun Kabupaten Aceh Barat. Sedangkan dibeberapa spanduk lainnya tertulis kata ucapan yaitu "Selamat Hari Raya Idul Adha" yang disampingnya (ujung kanan Baliho) juga ada pesan politik "SOLUSI NYATA UNTUK ACEH BARAT".

\section{$>\quad$ Strategi Visual}

Strategi visual dalam iklan politik pasangan Fuad Hadi, SH.,MH dan drh. Muhammad Arif terkesan berbeda dengan dua pasangan lainnya. Bila $\mathrm{H}$. T Alaidinsyah dan H. Kamaruddin menggunakan kibaran bendera Merah Putih dan pasangan H. Ramli, MS dan H. Banta Puteh Syam menggunakan latar belakang Merah sebagai lambang dari Partai Aceh, sedangkan pasangan Fuad Hadi, SH.,MH dan drh. Muhammad Arif menggunakan latar belakang gambar masjid Agung Kota Meulaboh sebagai salah satu icon yang melambangkan Kabupaten Aceh Barat sebagai salah satu Kabupaten yang Islami.

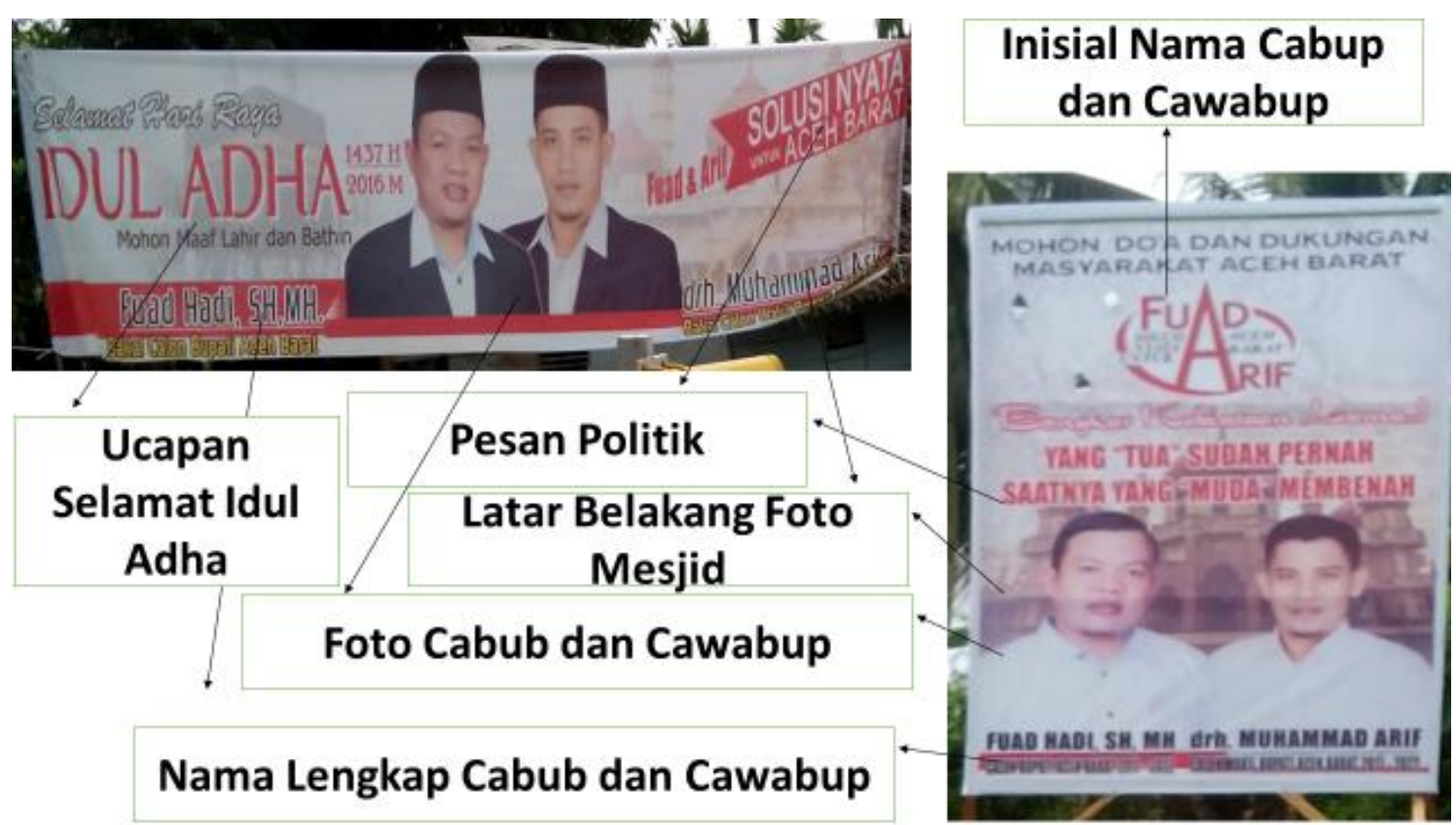

Gambar 4. Strategi Visual Iklan Politik Pasangan Fuad Hadi, SH.,MH dan drh.

Sumber: Foto Dokumen Pribadi

\section{Muhammad Arif (Fuad-Arif)}

\section{Strategi Media}

\section{$>\quad$ Memilih Audience Sasaran}

Audiens sasaran yang dituju oleh pasangan Fuad Hadi, SH.,MH dan drh. Muhammad Arif dalam iklan politiknya lebih fokus pada sasaran utama, yaitu masyarakat kabupaten Aceh Barat.

\section{$>\quad$ Menentukan Tujuan Media}

Mengamati penggunaan media untuk iklan politik pasangan Fuad Hadi, SH.,MH dan drh. Muhammad Arif terlihat bahwa media bukan menjadi hal yang utama untuk meraih dukungan politik dari masyarakat Kabupaten Aceh Barat. Hal inilah yang menjadi 
pembedanya dengan H. T Alaidinsyah dan H. Kamaruddin dan H. Ramli, MS dan H. Banta Puteh Syam yang cenderung lebih seimbang antara pemanfaatan media dan membangun jaringan di daerah. Frekuensi penayangan iklan politik pasangan Fuad Hadi, SH.,MH dan drh. Muhammad Arif lebih gencar pasca resmi mendaftarkan diri ke KIP Aceh Barat. Media mulai menayangkan berbagai berita tentang kedua pemuda Cabup dan Cawabup Aceh Barat ini.

\section{$>\quad$ Pemilihan Media dan Sarana}

Pemilihan media dan sarana untuk kepentingan kampanye dalam bentuk iklan politik pasangan Fuad Hadi, SH.,MH dan drh. Muhammad Arif lebih memilih iklan media online dan media cetak surat kabar dan spanduk.

\section{$>\quad$ Pembelian Media (Waktu Tayang dan Tempat Iklan)}

Pembelian waktu tayang untuk iklan politik pasangan Fuad Hadi, SH.,MH dan drh. Muhammad Arif lebih ditonjolkan di media online dan media cetak.

\section{PENUTUP}

Dari uraian di atas dapat disimpulkan bahwa peran media dalam komunikasi politik tidak menjadi strategi yang utama untuk mencapai tujuan bila tidak dilakukan secara seimbang mulai dari proses perencanaan media hingga ke pembelian media. Namun jika semuanya dilakukan secara seimbang, maka peran media sangat mempengaruhi masyarakat (pemilih) pada saat pemilukada nanti. Dari ketiga pasangan Cabup dan Cawabup Kabupaten Aceh Barat, dapat dilihat bahwa setiap pasangan memiliki ciri dan penyampaian pesan yang berbeda untuk menarik perhatian dari masyarakat.

Pilihan kalimat yang singkat dan tepat adalah salah satu unsur yang membuat masyarakat tertarik untuk mendukung atau tidak mendukung suatu calon. Namun seiring perkembangan zaman, melalui media, baik media cetak maupun elektronik, para pasangan Cabup dan Cawabup dapat mempromosikan dirinya dengan segala program-program atau visi dan misi kedepan saat menjabat sebagai Bupati dan Wakil Bupati Aceh Barat dari masing-masing pasangan calon. Dengan demikian, masyarakat sebagai penentu atau pemilih dapat menentukan siapa yang terbaik untuk menjadi Bupati danWakil Bupati mereka selama lima tahun ke depan.

\section{DAFTAR PUSTAKA}

Acehtrend.co. 2016. Media Online. Sudirman. Ini Alasan Haji Tito Gandeng Haji Kamaruddin di Pilkada Aceh Barat. Dapat diakses di http://www.acehtrend.co/inialasan-haji-tito-gandeng-haji-kamaruddin-di-pilkada-aceh-barat// diakses pada tanggal 10 Oktober 2016. Jam 21:00

Antar, Venus. 2004. Manajemen Kampanye; Panduan Teoritis Dan Praktis Dalam Mengefektifkan Kampanye Komunikasi. Bandung: Simbiosa Rekaatam Media

Astrid S. Susanto. 1980. Komunikasi Sosial di Indonesia. Bandung: Bina Cipta.

Cangara, Hafied. 2009. Komunikasi Politik: Konsep, Teori dan Strategi. Jakarta: Rajawali Pers. 
Firmanzah. 2008. Marketing Politik: Antara Pemahaman dan Realitas. Jakarta: Yayasan Obor Indonesia.

Kantaprawira, Rusadi. 1983. Sistem Politik Indonesia: Suatu Model pengantar. Bandung: Sinar Baru

Nimmo. 2001. Komunikasi Politik; Khalayak dan Efek, Bandung: Remaja Rosdakarya.

Pawito. 2009. Komunikasi Politik: Media Massa dan Kampanye Pemilihan. Yogyakarta \& Bandung: Jalasutra.

Serambi Indonesia. 2016. Media Cetak dan Media Online. 10 Agustus 2016. Fuad-Arif di Aceh Barat. Dapat diakses di http://aceh.tribunnews.com/2016/08/10/fuad-arif-diaceh-barat

Shimp, Terence A. 2003. Periklanan \& Promosi: Aspek Tambahan Komunikasi Pemasaran Terpadu Edisi Kelima Jilid II. Jakarta: Erlangga. 